\title{
Cytotoxicity, Redox and Immune Status in African Catfish, Clarias Gariepinus (Burchell, 1822) Exposed to Bisphenol a (BPA) and its Analogues
}

\author{
Oluwakemi D. Samuel \\ Federal University of Technology Akure \\ Joseph Adeyemi ( $\nabla$ joseph.adeyemi@gmail.com ) \\ Universidade de Sao Paulo https://orcid.org/0000-0003-2250-5862 \\ Olufemi S. Bamidele \\ Federal University of Technology Akure \\ Fernando Barbosa Jr \\ University of Sao Paulo: Universidade de Sao Paulo \\ Chris O. Adedire \\ Federal University of Technology Akure
}

\author{
Research Article \\ Keywords: BPA, BPA analogues, fish, oxidative stress, fish hematology, humoral immunity \\ Posted Date: September 13th, 2021 \\ DOI: https://doi.org/10.21203/rs.3.rs-812931/v1 \\ License: (c) (i) This work is licensed under a Creative Commons Attribution 4.0 International License. Read Full License
}




\section{Abstract}

The objective of the study was to determine the comparative toxicities and immune dysfunction in the African catfish, Clarias gariepinus exposed to bisphenol A (BPA) and its two analogues; bisphenol AP (BPAP) and bisphenol P (BPP). Juveniles of $C$. gariepinus were exposed to sublethal concentrations (70 and $140 \mu \mathrm{g} / \mathrm{L}$ ) of BPA, BPAP and BPP for 7, 14, or 21 days after which various endpoints which are indicative of cytotoxicity, oxidative stress, haematological and innate immune parameters were determined in the liver homogenates or blood plasma. The exposure of $C$. gariepinus to BPA and its analogues caused significant increased activities of lactate dehydrogenase, catalase and superoxide dismutase. The exposed fish had increased levels of DNA fragmentation, lipid peroxidation, white blood cells, nitric oxide and respiratory burst while the red blood cells counts and the percentage packed cell volume decreased significantly in the exposed fish compared to control. The toxic effects elicited by the bisphenols were both concentration- and duration-dependent. Generally, BPA exerted the most toxic effects on the fish, followed by BPAP while BPP exerted the least toxic effect effects to $C$. gariepinus. Summarily, the findings indicated that BPA and its two analogues studied in the research are capable of causing cytotoxicity, oxidative stress and immune dysfunction in C. gariepinus.

\section{Introduction}

Bisphenol A (BPA) is an anthropogenic industrial chemical, which is widely used as a monomer or additive in the production of polycarbonates (PCs), epoxy resins, and other polymeric materials (Huang et al. 2012). BPA is used mainly in the production of polycarbonate plastics which are often used in plastic food-storage containers, reusable water bottles, and baby bottles and epoxy resins which are used to coat the inside of food, beverage cans, coils, and water-supply pipes. The global volume of BPA consumption for different application areas was estimated at 7.7 million metric tons in 2015 , and it was forecasted to reach 10.6 million metric tons in 2022 (Global Industry Analysts Inc 2015).

Due to its widespread use in many commercial and industrial products, BPA has been frequently detected in varying concentrations in various environmental matrices such as soil and water and in thermal receipts (Arnold et al. 2013; Adeyemi et al. 2020). The aquatic ecosystems are continuously being exposed to BPA either through its direct release in processes such as manufacturing, processing, and transport or by indirect release as landfill leachates, natural breakdown of BPA products, and wastewater treatment (Flint et al. 2012).

The contamination of the aquatic systems with BPA causes serious problems to the health of aquatic organisms and its detrimental effects on aquatic ecology have been a matter of great concern (Rochester 2013). The various toxic effects of BPA and its analogues in fish are well documented in the literature. BPA is a known endocrine-disrupting chemical, and has been reported to modulate hormonal activities in fish (Crain et al. 2007). BPA appears to have complex immuno-modulatory effects, which may stimulate or suppress the immune system (Michałowicz 2014), and can significantly impact growth, morphology, biochemical variables and histological structure of fish (AbdelTawwab and Hamed 2018). Faheem and Lone (2018) reported a significant increase in the level of lipid peroxidation, glutathione-S-transferase activity and decrease in reduced glutathione content in Ctenopharyngodon idella exposed to a sublethal concentration of BPA for 14 days. Also, Krishnapriya et al. (2017) reported a decrease in red blood cell counts but an increase in white blood cell counts in fingerlings of Labeo rohita exposed to sublethal concentrations (2, 4, 6, 8 and 10 mg/L) of BPA for 35 days. The exposure of Fathead minnows to $16-1280 \mu \mathrm{g} / \mathrm{L}$ BPA for 164 days resulted in inhibition of gonadal growth and spermatogenesis (Sohoni et al. 2001). Medaka fish that were exposed to $10 \mu \mathrm{g} / \mathrm{L}$ BPA for 10 weeks had reduced number of eggs and hatchlings (Shioda and Wakabayashi 2000). In another study, Kwak et al. (2001) reported apoptosis of testicular cells in the freshwater Swordtail fish that were exposed to $2000 \mu \mathrm{g} / \mathrm{L}$ BPA for $60 \mathrm{days}$.

Over the past two decades, more than 20 new structural analogues of BPA such as bisphenols S, F, AF, P, AP etc. have been produced for various industrial and commercial applications, and they are generally assumed to be less toxic compared to BPA. Interestingly, few studies have reported the various toxic effects of these analogues although such data are still few (Chen et al. 2016). The present study is therefore aimed at determining the comparative toxicity and immune dysfunction in African catfish, Clarias gariepinus exposed to bisphenol A and its two analogues; bisphenols AP and P.

\section{Materials And Methods}

\section{Experimental organism}

The experimental animal used in the study was juvenile African catfish, Clarias gariepinus of average weight of $24 \pm 3.0 \mathrm{~g}$ and length of $8 \pm 2.0 \mathrm{~cm}$. The fish were purchased from a reputable fish farm in Akure and were transported to the Research Laboratory of Department of Biology, Federal University of Technology, FUTA in an appropriate containers under mild aeration. The fish were acclimatized to laboratory conditions, temperature: $25 \pm 2{ }^{0} \mathrm{C}, 14 \mathrm{~h}$ light: $10 \mathrm{~h}$ dark cycle for 7 days, prior to use for experiments. They were fed with commercial fish pellet twice daily throughout the period of acclimatization. After the seven-day period of laboratory acclimatization, the fish were randomly allocated into seven groups ( $\mathrm{n}=10$ per group) and were distributed into the experimental tanks. The fish were exposed to either $70 \mu \mathrm{g} / \mathrm{L}$ or $140 \mu \mathrm{g} / \mathrm{L}$ of BPA, BPAP AND BPP for 21 days. The control fish were maintained in uncontaminated water. During the bisphenol exposure duration, fish were fed twice daily with a commercial diet having $25 \%$ crude protein and the excess fish feed were siphoned daily from each aquarium. The exposure followed a static renewal approach, in which the test solutions were renewed every $48 \mathrm{~h}$. On the days 7, 14 and 21 of exposure, representative samples from each group were collected, euthanized with tricaine, and sacrificed. Blood samples were collected through the caudal veins of randomly selected fish into EDTA bottles for haematological and innate humoral immunity assessment. The liver was excised and stored in $-20^{\circ} \mathrm{C}$ for later assessment of cytotoxicity and determination of the redox status.

\section{Samples preparation}


A portion of the collected whole blood was immediately used for the analysis of haematological parameters such as white blood cells (WBC) count, red blood cells (RBC) count, haematocrit and differential white blood cells count (lymphocytes, monocytes, neutrophils, eosinophils, and basophils). The plasma was obtained from the other portion of the whole blood by subjecting the blood to centrifugation at $10,000 \times \mathrm{g}$ for $10 \mathrm{~min}$, and the obtained plasma was subsequently used for nitric oxide and respiratory burst. The excised liver tissues were homogenized using a homogenizer in ice-cold potassium phosphate buffer $(0.05 \mathrm{M}, \mathrm{pH} 7.4)$ in the ratio of $1 \mathrm{~g}$ of tissue to $3 \mathrm{~mL}$ of buffer. The resulting homogenate was centrifuged at $10,000 \times \mathrm{g}$ for $15 \mathrm{~min}$ at $4{ }^{\circ} \mathrm{C}$. Both the supernatant and pellet obtained were stored at $-20^{\circ} \mathrm{C}$ for antioxidants assays (SOD, GSH, CAT, and MDA), lactate dehydrogenase and DNA fragmentation assays.

\section{Protein determination}

The protein content of the fish homogenate was determined using the method of Bradford (1976), and bovine serum albumen was used as the standard.

\section{Determination of lactate dehydrogenase activity}

The lactate dehydrogenase assay was determined using the method of Howell et al. (1979).

Briefly, $950 \mu \mathrm{L}$ of potassium phosphate buffer (50 mM, pH 7.4), $250 \mu \mathrm{L}$ of $6 \mathrm{mM}$ NAD solution and $250 \mu \mathrm{L}$ of $150 \mathrm{mM}$ lactic acid solution were pipetted into a tube followed by addition of $50 \mu \mathrm{L}$ of the homogenate to start the reaction. The change in absorbance was monitored for $1 \mathrm{~min}$ at $340 \mathrm{~nm}$ using $\mathrm{UV} / \mathrm{visible} \mathrm{spectrophotometer.} \mathrm{The} \mathrm{activity} \mathrm{was} \mathrm{expressed} \mathrm{as} \mu \mathrm{mol} \mathrm{NADH} / \mathrm{min} / \mathrm{mg}$ protein using $6220 \mathrm{M}^{-1} \mathrm{~cm}^{-1}$ as extinction coefficient.

\section{Level of DNA fragmentation}

The method of Gercel-Taylor (1982) was employed for the determination of DNA fragmentation. Briefly, $1 \mathrm{~mL}$ Tris-EDTA buffer (10 mM Tris-Cl, 1 mM EDTA, $\mathrm{pH}$ 7.4) was added to the pellet obtained from the liver homogenate and mixed thoroughly. A second centrifugation was done at $10,000 \times \mathrm{g}$ for 10 min and the supernatant obtained was transferred into a new tube labelled T. Another $1 \mathrm{~mL}$ of Tris-EDTA buffer was added to the pellet obtained from the second centrifugation and the tube was labelled B. Thereafter, $600 \mu \mathrm{L}$ of $5 \%$ Trichloroacetic acid (TCA) was added to both tubes B and T and were mixed thoroughly. The tubes were left overnight in the refrigerator and centrifuged for the third time at 10,000 $\times \mathrm{g}$ for $10 \mathrm{~min}$. The supernatant was discarded and $320 \mu \mathrm{L}$ of $5 \%$ TCA was added to both tubes, and was placed on heat at $90^{\circ} \mathrm{C}$ for 15 minutes. Later, $640 \mu \mathrm{L}$ of freshly prepared diphenyl amine (DPA) solution was added to the tubes, and vortex thoroughly. The colour was allowed to develop for about $4 \mathrm{~h}$ at $37^{\circ} \mathrm{C}$ and the absorbance was measured at $620 \mathrm{~nm}$ using UV spectrophotometer. The level of DNA fragmentation was expressed as percentage fragmented DNA using the formulae:

$\%$ fragmented DNA $=100 \mathrm{~T} / \mathrm{T}+\mathrm{B}$

Where $T$ and $B$ are the absorbance values of tubes $T$ and $B$ respectively.

\section{Level of reduced glutathione (GSH)}

The level of reduced glutathione was estimated by the method of Ellman et al. (1959) with slight modification. A 200 mg of fresh liver sample was added to $2 \mathrm{~mL}$ of $2 \%$ metaphosphoric acid and $0.6 \mathrm{~mL}$ of $10 \%$ sodium citrate, and were homogenized. The resulting homogenate was centrifuged at $4000 \mathrm{rpm}$ for $10 \mathrm{~min}$. The reaction mixture contains $1.0 \mathrm{~mL}$ of the supernatant, $0.1 \mathrm{~mL}$ of distilled water, $0.1 \mathrm{~mL}$ of 5,5 '-dithiobis nitro benzoic acid (DTNB), $0.69 \mathrm{~mL}$ of nicotinamide adenine dinucleotide phosphate hydrogen (NADPH) and $0.01 \mathrm{~mL}$ of glutathione reductase (GR), and was incubated for $15 \mathrm{~min}$ at room temperature. The intensity of yellow colour formed was measured at $420 \mathrm{~nm}$ along with blank containing $1.0 \mathrm{~mL}$ of distilled water. The amount of GSH was expressed as $\mathrm{nmol} \mathrm{GSH} / \mathrm{mg}$ protein.

\section{Level of lipid peroxidation}

The concentration of malondialdehyde (MDA), a product of lipid peroxidation was measured according to the method described by Varshney and Kale (1990). Briefly, $200 \mu \mathrm{L}$ of the supernatant was mixed with $1.8 \mathrm{~mL}$ of Tris-Hcl buffer before $500 \mu \mathrm{L}$ of trichloroacetic acid (30\%) was added. Then, $50 \mu \mathrm{L}$ of thiobarbituric acid $(0.75 \% \mathrm{w} / \mathrm{v})$ was added and the reaction mixture was centrifuged at $4000 \times \mathrm{g}$ for 5 min. The reaction mixture was incubated at 95 ${ }^{\circ} \mathrm{C}$ for $45 \mathrm{~min}$. The mixture was allowed to cool to room temperature and absorbance of the resulting supernatant was read at $532 \mathrm{~nm}$ using $\mathrm{UV}$ spectrophotometer against reference blank containing deionized water and subsequently calculated and expressed as $\mathrm{mmol} / \mathrm{mg} \mathrm{protein}$.

\section{Catalase (CAT) activity}

The catalase activity was determined according to the method of Aebi (1984). To $1.8 \mathrm{ml}$ of potassium phosphate buffer (100 mM, pH 7.0) was added $0.1 \mathrm{~mL}$ of tissue homogenate and the enzyme reaction started by the addition of $0.1 \mathrm{~mL}$ of $\mathrm{H}_{2} \mathrm{O}_{2}$ solution. The decrease in absorbance was measured at $240 \mathrm{~nm}$. The enzyme blank was run simultaneously with $0.05 \mathrm{~mL}$ of distilled water instead of hydrogen peroxide. The enzyme activity is expressed as $\mu \mathrm{moles} / \mathrm{min} / \mathrm{mg}$ protein.

\section{Superoxide dismutase (SOD) activity}


Superoxide dismutase activity was determined according to the method of Beauchamp and Fridovich (1971), in which $0.25 \mathrm{~mL}$ of tissue homogenate was treated with $1.5 \mathrm{~mL}$ of SOD reagent (1.17 mM riboflavin, $0.1 \mathrm{M}$ methionine, $20 \mathrm{mM}$ potassium thiocyanide, $56 \mathrm{mM}$ nitro blue tetrazolium). The mixture was incubated for $1 \mathrm{~h}$ at room temperature. Blank was also prepared simultaneously with distilled water replacing tissue homogenate and was incubated for same period of time in dark cupboard. SOD activity was expressed as $\mu \mathrm{moles} / \mathrm{min} / \mathrm{mg}$ protein.

\section{Total red blood cell (RBC) counts}

Total RBC count was determined according to the method described by Rusia and Sood (1992). Briefly, $0.02 \mathrm{~mL}$ blood was mixed with $3.98 \mathrm{~mL}$ of diluting fluid (Hayem's solution; $0.25 \mathrm{~g}$ of mercury (II) chloride, $2.50 \mathrm{~g}$ of sodium sulphate, and $0.5 \mathrm{~g}$ of sodium chloride in $100 \mathrm{ml}$ of distilled water). The Neubauer chamber was charged with well-mixed diluted blood. The total number of red cells in the small square in the central ruled area of Neubauer counting chamber was counted using $\times 40$ objective of the microscope. Total RBC count $=$ Number of cells counted $\times 10,000$ count $/ \mathrm{mm}^{3}$.

\section{Percentage packed cell volume}

The microhaematocrit method of Snieszko (1960) was used to determine the hematocrit (PCV). The capillary tube was filled with blood of about $3 / 4$ of of the blood sample in heparinized tube by capillary action. One end of the tube was sealed with plasticizer. The blood in the capillary tube was centrifuged at $1200 \mathrm{rpm}$ for 5 min using micro microhaematocrit centrifuge and the PCV was read using microhaematocrit reader. The haematocrit level was quantified as the percentage of the volume of red blood cells in the total volume of the whole blood.

\section{Total white blood cell (WBC) counts}

Total WBC count was determined according to the method of Rusia and Sood (1992). Briefly, $0.02 \mathrm{~mL}$ blood was mixed with to $0.38 \mathrm{~mL}$ of diluting fluid (Turk's solution; $0.2 \mathrm{ml}$ of gentian violent $1 \%, 2 \mathrm{~mL}$ of acetic acid $10 \%$ and $98 \mathrm{~mL}$ of distilled water). The Neubauer counting chamber was charged with the well-mixed diluted blood. The total number of white blood cells in the four large corner squares of chamber was counted after 3-4 min. Total WBC count $=$ Number of cells counted $\times 50$ count $/ \mathrm{mm}^{3}$.

\section{Differential leucocytes counts}

Differential counts such as neutrophils, lymphocytes and monocytes were determined on blood film stained with May-Grunwald-Giemsa stain (Penttilä et al. 1985). The differential WBC was done by preparing smears of collected blood on clean slides, allowed to air-dry at room temperature, stained with May-Grunwald-Giemsa stain for 30 min and the slides were observed under microscope. A total of 100 WBCs were counted per slide.

\section{Levels of nitric oxide}

The method of Guevara-Guzman et al. (1994) was adopted for the determination of nitric oxide levels. The tissue supernatants obtained was deproteinized by addition of equal volume of $4 \%$ sulfosalicyclic acid, $0.35 \mathrm{ml}$ of the reaction mixture was made to react with $0.35 \mathrm{ml}$ of Griess' reagent. ( $1: 1$ mixture of $1 \%$ sulfanilamide in $5 \%$ phosphoric acid and $0.1 \%$ of $\mathrm{N}$-1-naptyl ethylenediamine (NED) in distilled water) and incubate for 10 min in dark at room temperature. The absorbance of the assay sample was measured at $540 \mathrm{~nm}$ in UV spectrophotometer. Nitrate concentration were calculated using a calibration curve prepared from sodium nitrate and expressed as nmole/mL.

\section{Level of respiratory burst}

The level of respiratory was determined by the method of Anderson and Siwicki (1995). A $100 \mu \mathrm{L}$ of blood plasma was mixed with $100 \mu \mathrm{L}$ of $0.2 \%$ nitroblue tetrazolium solution which was homogenized and incubated for $30 \mathrm{mins}$ at $25^{\circ} \mathrm{C}$. The NBT solution was prepared in phosphate buffered saline (PBS, prepared with $\mathrm{NaCl}(0.137 \mathrm{M}), \mathrm{KCl}(2.7 \mathrm{mM}), \mathrm{KH}_{2} \mathrm{PO}_{4}(1.5 \mathrm{mM}), \mathrm{Na}_{2} \mathrm{HPO}_{4}(8.1 \mathrm{mM}), \mathrm{CaCl}_{2}(0.9 \mathrm{mM}), \mathrm{MgCl}_{2}(0.49 \mathrm{mM})$ in distilled water Milli-Q qsp 1 litre), pH 7.4. $50 \mu \mathrm{l}$ from the mixture was added to $1 \mathrm{ml}$ of $\mathrm{N}, \mathrm{N}$-dimethyl formamide in a glass tube. The solution was properly homogenised and afterwards centrifuged at $3000 \times \mathrm{g}$ for $5 \mathrm{~min}$. The optical density of the supernatants was measured at $540 \mathrm{~nm}$ on a UV spectrophotometer against a blank with same components except the blood was exchanged with distilled water.

\section{Statistical analysis}

Data analysis was performed using the Graphpad Prism version 5.0 (Graphpad prism software, Inc., San Deigo, California). The results were analysed using two-way analysis of variance (ANOVA), followed by Tukey's test and data were presented as means \pm standard deviation (SD). Statistical significance was assumed at $\mathrm{p}<0.05$.

\section{Results}

\section{Lactate dehydrogenase activity}

The results of the activity of lactate dehydrogenase (LDH) are shown in Figure 1A. The activity of LDH increased significantly due to the exposure to the Bisphenols compared to the control except for the fish that were exposed to $70 \mu \mathrm{g} / \mathrm{L}$ of BPP $\left(F_{6,42}=176.45 ; p<0.0001\right)$. The activity of lactate dehydrogenase was highest in fish exposed to $140 \mu \mathrm{g} / \mathrm{L}$ BPA $(9.06 \pm 0.412,13.18 \pm 0.412$, and18.94 $\pm 1.089 \mu \mathrm{mol}$ NADH/mg protein for 7-, 14 -, and 21-day exposure durations respectively) while fish exposed to $140 \mu \mathrm{g} / \mathrm{L}$ of BPP had the lowest LDH activity $(6.17 \pm 0.012,7.00 \pm 0.412$ and $10.71 \pm 0.412 \mu \mathrm{mol}$ 
$\mathrm{NADH} / \mathrm{mg}$ protein for 7-, 14-, and 21-day exposure durations respectively). The LDH activity increased with increasing exposure duration such that the activity of LDH was highest after 21 days exposure for all the treatment groups in comparison to the 7- and 14-day exposure durations $\left(F_{2,42}=144.76 ; p\right.$ $<.0001)$. There was a strong interactive effects of concentrations of Bisphenols and exposure duration on the activity of lactate dehydrogenase in $C$. gariepinus $\left(\mathrm{F}_{12,42}=6.21 ; \mathrm{p}<.0001\right)$.

\section{Levels of DNA fragmentation}

The levels of DNA fragmentation in $C$. gariepinus following exposure to bisphenols are presented in Figure 1B. The exposure of $C$. gariepinus to BPA, BPAP, and BPP resulted in an increase in the percentage of fragmented DNA compared to the control irrespective of the exposure duration

$\left(F_{6,42}=165.47 \mathrm{p}<.0001\right)$. The percentage of fragmented DNA was highest in the fish exposed to the two concentrations of BPA tested in this study $(70$ and $140 \mu \mathrm{g} / \mathrm{L}$ ), followed by the fish exposed to BPAP and lowest in fish exposed to BPP. The percentage of fragmented DNA increased with increasing exposure duration with the levels of DNA fragmentation being highest after 21 days exposure for all the treatment groups $\left(F_{2,42}=263.07 p<.0001\right)$. There was a strong interaction between the concentration of Bisphenols and exposure duration on the levels of DNA fragmentation $\left(F_{12,42}=9.96 p<\right.$ .0001).

\section{Levels of lipid peroxidation (LPO)}

The levels of lipid peroxidation in $C$. gariepinus exposed to Bisphenols are shown in Figure $2 \mathrm{~A}$. The statistical analyses of the data indicated that the level of LPO increased significantly in fish exposed to different concentrations of Bisphenols compared to control $\left(F_{6,42}=187.33 ; p<.0001\right)$. However, there was no significant difference in the levels of LPO between the control and the group exposed to $70 \mu \mathrm{g} / \mathrm{L}$ of BPP for the 7-day exposure duration. Similarly, the levels of lipid peroxidation increased with increasing exposure duration $\left(F_{2,42}=147.54 ; p<.0001\right)$. The interaction between Bisphenol concentration and exposure duration was statistically significant $\left(F_{12,42}=5.07 ; p<.0001\right)$.

\section{Levels of reduced glutathione (GSH)}

The levels of GSH in C. gariepinus following exposure to bisphenols are shown in Figure 2B. There was a significant decrease in the levels of GSH in fish exposed to bisphenols compared to the control $\left(F_{6,42}=238.47 ; p<.0012\right)$. Among the treatment groups, the levels of $G S H$ was highest in fish exposed to $70 \mu \mathrm{g} / \mathrm{L}$ of $\operatorname{BPP}(5.26 \pm 0.261,4.51 \pm 0.106,4.44 \pm 0.089 \mu \mathrm{mol} \mathrm{GSH} / \mathrm{mg}$ protein for 7-, 14- and 21-day exposure durations respectively) while the levels of GSH was lowest in fish exposed to $140 \mu \mathrm{g} / \mathrm{L}$ of BPA $(2.78 \pm 0.170,1.79 \pm 0.037,0.89 \pm 0.279 \mu \mathrm{mol} \mathrm{GSH} / \mathrm{mg}$ protein for 7 -, 14 - and 21 -day exposure durations respectively). There was a significant effect of exposure duration of the levels of $G S H$ in the fish $\left(F_{2}, 42=63.42 ; p<.0001\right)$. Generally, the levels of GSH reduced with increasing exposure duration. There was a strong interactive effect of concentration of Bisphenols and exposure duration on the levels of $\mathrm{GSH}\left(\mathrm{F}_{12,42}=3.52 ; \mathrm{p}<.0012\right)$.

\section{Catalase activity}

The data on the activity of catalase (CAT) are shown in Figure 2C. The activity of CAT increased significantly due to the exposure to Bisphenols compared to the control except for the fish exposed to $70 \mu \mathrm{g} / \mathrm{L}$ of BPP at the 7-day exposure duration $\left(F_{6,42}=513.67 ; \mathrm{p}<.0001\right)$. At each exposure duration, the activity of CAT was highest in fish exposed to BPA, followed by fish exposed to BPAP and lowest in fish exposed to BPP. Also, there was a significant effect of exposure duration on the activity of catalase in the fish with the activity being highest in fish after 21 days of exposure to the Bisphenols compared to 7 and 14 days of exposure $\left(F_{2,42}=313.86 ; p<.0001\right)$. There was a strong interaction between the effects of concentrations of Bisphenols and exposure duration on the activity of CAT in $C$. gariepinus $\left(F_{12,42}=14.10 ; p<.0001\right)$.

\section{Superoxide dismutase (SOD) activity}

The data on the activity of superoxide dismutase following exposure of $C$. gariepinus to bisphenols are presented in Figure 2D. There was a significant increase in the CAT activity due to exposure to Bisphenols compared to the control except for the fish exposed to $70 \mu \mathrm{g} / \mathrm{L}$ of BPP at the 7 -day exposure duration $\left(F_{6,42}=223.63 ; \mathrm{p}<.0001\right)$. The activity of SOD was highest in fish exposed to $140 \mu \mathrm{g} / \mathrm{L} \mathrm{BPA}(4.95 \pm 0.21,6.05 \pm 0.04$, and 7.31 $\pm 0.41 \mathrm{U} / \mathrm{mg}$ protein for 7-, 14-, and 21-day exposure durations respectively) while fish exposed to $70 \mu \mathrm{g} / \mathrm{L}$ of BPP had the lowest SOD activity (1.96 $\pm 0.14,2.65 \pm 0.06$ and 3.64 $\pm 0.07 \mathrm{U} / \mathrm{mg}$ protein for 7-, 14-, and 21-day exposure durations respectively). The SOD activity increased with increasing exposure duration such that the activity of SOD was highest after 21 days exposure for all the treatment groups in comparison to the 7-and 14-day exposure durations $\left(F_{2,42}=\right.$ $113.49 ; \mathrm{p}<.0001)$. There was a strong interactive effects of concentrations of Bisphenols and exposure duration on the activity of SOD in $C$. gariepinus $\left(F_{12,42}=5.04 ; p<.0003\right)$.

\section{Red blood cells (RBC) counts}

The total red blood cell counts in C. gariepinus exposed to different concentrations to Bisphenols are shown in Figure 3A. The red blood cells counts decreased significantly in fish exposed to the Bisphenols compared to the control $\left(F_{6,42}=516.25 ; p<.0001\right)$. At the three exposure durations, the RBC counts were lowest in fish exposed to BPA, followed by the group exposed to BPAP, and highest in the group exposed to BPP. The RBC counts decreased with increasing exposure duration such that the RBC counts was lowest after 21 days exposure for all the treatment groups in comparison to the 7- and 
14-day exposure durations $\left(F_{2,42}=418.58 ; \mathrm{p}<.0001\right)$. There was a strong interactive effects of concentrations of Bisphenols and exposure duration on the RBC counts in $C$. gariepinus $\left(\mathrm{F}_{12,42}=20.32 ; \mathrm{p}<.0003\right)$.

\section{Percentage packed cell volume (PCV)}

The data on percentage packed cell volume in C. gariepinus exposed to different concentrations to Bisphenols are presented in Figure 3B. There was a significant decrease in percentage PCV in fish exposed to the Bisphenols compared to the control $\left(F_{6,42}=177.57 ; p<.0001\right)$. At the three exposure durations, the percentage PCV were lowest in fish exposed to BPA, followed by the group exposed to BPAP, and highest in the group exposed to BPP. The percentage PCV decreased with increasing exposure duration such that the percentage PCV was lowest after 21 days exposure for all the treatment groups in comparison to the 7- and 14-day exposure durations $\left(F_{2,42}=136.76 ; p<.0001\right)$. There was a strong interactive effects of concentrations of Bisphenols and exposure duration on the percentage PCV in $C$. gariepinus $\left(F_{12,42}=3.72 ; \mathrm{p}<.0003\right)$.

\section{White blood cells counts}

The data on the total white blood cells counts following exposure of $C$. gariepinus to bisphenols are presented in Figure $3 \mathrm{C}$. There was a significant increase in the total white blood cells counts due to exposure to Bisphenols compared to the control $\left(F_{6,42}=2434 ; p<.0001\right)$. The total white blood cells counts was highest in fish exposed to $140 \mathrm{\mu g} / \mathrm{L}$ BPA $\left(20.28 \pm 0.10,26.40 \pm 0.36\right.$, and $30.83 \pm 0.09\left(\times 10^{3} / \mathrm{mm}^{3}\right)$ at 7-, 14-, and 21-day exposure durations respectively) while fish exposed to $70 \mu \mathrm{g} / \mathrm{L}$ of BPP had the lowest total WBC counts $\left(15.22 \pm 0.09,20.22 \pm 0.03\right.$ and $24.83 \pm 0.14\left(\times 10^{3} / \mathrm{mm}^{3}\right)$ at $7-, 14-$, and 21-day exposure durations respectively). The total WBC counts increased with increasing exposure duration such that the total WBC counts was highest after 21 days exposure for all the treatment groups in comparison to the 7- and 14-day exposure durations $\left(F_{2,42}=8080.98 ; p<.0001\right)$. There was a strong interactive effects of concentrations of Bisphenols and exposure duration on the total WBC counts in $C$. gariepinus $\left(\mathrm{F}_{12,42}=256.93 ; \mathrm{p}<.0003\right)$.

\section{Differential white blood cells count}

The data on differential white blood cells counts are shown on Table 1. There was statistical significant difference in the percentage lymphocytes, neutrophils, and monocytes among the different groups. The percentage lymphocytes, neutrophil, and monocytes ranged between 70-88, 10-15, and 5$10 \%$ respectively. The exposure duration had a significant effect on the differential white blood cell counts. There was a strong interactive effects of concentrations and exposure duration.

\section{Plasma levels of nitric oxide}

The plasma levels of nitric oxide in $C$. gariepinus exposed to bisphenols are shown in Figure 4A. There was a significant increase in the nitric oxide production in all the treatment groups in comparison to the control $\left(F_{6,42}=512 ; p<.0001\right)$. At the both concentrations tested in the study, the plasma levels of nitric oxide was least in fish exposed to BPP, followed by those exposed to BPAP, and highest in fish exposed to BPA. Also, nitric oxide level increased significantly in fish with increasing exposure duration $\left(F_{2,42}=89.64 ; p<.0001\right)$. Again, strong interactive effect was observed between the effects of concentrations of Bisphenols and exposure duration $\left(F_{12,42}=6.42 ; p<.0001\right)$.

\section{Respiratory burst activity}

The data on the respiratory burst activity in C. gariepinus exposed to Bisphenols are shown in Figure 4B. The respiratory burst differed significantly among the treatment groups $\left(F_{6,42}=857.19 ; \mathrm{p}<.0001\right)$. All the Bisphenol types used in the study increased the respiratory burst of the fish although at different magnitude; the respiratory burst was lowest in fish exposed to BPP followed by the group exposed to BPAP while respiratory burst was highest in fish exposed to BPA. There was a significant effect of exposure duration on the respiratory burst of $C$. gariepinus following exposure to

Bisphenols $\left(F_{2,42}=360.96 ; p<.0001\right)$. There was a strong interaction between concentrations of Bisphenols and the exposure duration $\left(F_{12,42}=12.92\right.$; $\mathrm{p}<.0001)$.

\section{Discussion}

The present study employed various biomarkers to investigate cytotoxicity, redox imbalance, and immune dysfunction in the African catfish, $C$. gariepinus due to exposure to bisphenol A and its two analogues; bisphenol AP and bisphenol P. The activity of lactate dehydrogenase and levels of DNA fragmentation were used as biomarkers of cytotoxicity in this study. Lactate dehydrogenase is a membrane enzyme, and its use as an index of cytotoxic effect in animals is quite common (Kumar et al. 2013; Parhamifar et al. 2019). Exposure to BPA and its analogues resulted in increased activity of lactate dehydrogenase in the liver of C. gariepinus. This was consistent with the findings of Lakshmaiah (2016) in which exposure to the organophosphate pesticide, phorate caused an increase in the activity of lactate dehydrogenase in the target organs of Cyprinus carpio. Similarly, the exposure of Labeo rohita to bisphenol A resulted in a significant increase in the activity of lactate dehydrogenase (Krishnapriya et al. 2017). The increased activity of lactate dehydrogenase in the liver of $C$. gariepinus could be an indication of suppression of oxidative metabolism in the exposed fish, and a shift to anaerobic respiration to meet the demand for increased energy demand in the exposed fish. This assertion was supported by the results of studies with Wistar rats that were chronically exposed to low doses of bisphenols $A$ and $S$ which showed alteration in mitochondrial energy metabolism in the exposed rats as well as upregulation of mitochondrial proteins that were involved in electron transport chain (Azevedo et al. 2019; Azevedo et al. 2020). Also, the level of DNA fragmentation has been used as a measure of cell death (Han et al. 2019). The exposure of $C$. gariepinus to 
BPA, BPAP, and BPP in the present study caused increased DNA fragmentation which is both concentration- and exposure duration-dependent. These findings were in tandem with the report of similar studies that reported increased levels of DNA fragmentation in fish under stress conditions (Martinez et al. 2012; Talukdar et al. 2017).

The maintenance of redox homeostasis in fish is important for the maintenance of physiological activities. Cellular metabolism results in the production of reactive oxygen species (ROS) such as hydroxyl ion, superoxide anions, nitric oxide, hydrogen peroxide etc. These ROS must be scavenged by enzymatic and non-enzymatic antioxidants so as to prevent oxidative stress. Oxidative stress results when the rate of production of ROS exceeds the scavenging activities of the antioxidants. Oxidative stress have been implicated in major human diseases and aging. At cellular and biochemical level, ROS bind to biomolecules such as nucleic acid, lipids and proteins resulting in the production of oxidized products of the molecules e.g. guanosylated nucleic acids, carbonylated proteins, and peroxidized lipids (Albuquerque et al. 2017). Among the oxidative stress markers, levels of lipid peroxidation and activities of antioxidant enzymes like catalase, superoxide dismutase, glutathione peroxidase etc. are the most common. In this study, all species of bisphenols caused a significant increase in the levels of lipid peroxidation, and activities of liver catalase (CAT) and superoxide dismutase (SOD) but a decrease in the levels of liver reduced glutathione in the fish. It has been documented in other studies that BPA and its analogues induced lipid peroxidation in fish by formation of hydroxyl radicals (Wu et al. 2011; Abdel-Tawwab and Hamed, 2018). The increased activities of catalase and superoxide dismutase observed in this study following exposure to bisphenols was similar to the reports of other studies with fish species. Kaya and Kaptaner (2016) reported an increased activity of hepatic SOD in fish exposed to bisphenol A. Similarly, Revathi et al. (2019) also reported a significant increase in the activities of catalase and SOD in the vital organs of Lates calcarifer exposed to $0.1 \mu \mathrm{g} / \mathrm{L}$ BPA. In another study, the exposure of male Medaka fish to bisphenol resulted into 5-20 fold upregulation of catalase mRNA (Qiu et al. 2016). The increased activity of superoxide dismutase (SOD) can be attributed to the fact that superoxide dismuatse converts superoxide anions into hydrogen peroxide and water, which is a major biochemical pathway in the antioxidant defense system. The levels of reduced glutathione in the exposed groups decreased significantly in comparison to the control fish. Generally, under stress conditions, reduced glutathione binds to RoS thus resulting in depletion of its cellular levels (Adeyemi et al. 2018; Adeyemi et al. 2020).

The haemato-immune parameters has been used in studies as biomarkers of stress in fish species (Adeyemi et al. 2014; Sharma and Chadha 2015; Aiswarya and James 2016; Owolabi and Babarinsa 2020). The haematological profiling in C. gariepinus exposed to BPA and its analogues indicated alterations in the red blood cells and white blood cells counts of the exposed fish. The RBC counts of exposed fish ranged between $0.48 \pm 0.02$ and 2.91 $\pm 0.05\left(\times 10^{6} / \mathrm{mm}^{3}\right)$ while the range values were $3.03 \pm 0.08$ and $3.64 \pm 0.06\left(\times 10^{6} / \mathrm{mm}^{3}\right)$ in unexposed fish. RBC is an important component that aid the transportation of respiratory gas. The reduction in RBC counts might induce hypoxia thus resulting into suffocation in the exposed fish. Similarly, the PCV values reduced significantly in fish exposed to BPA and analogues in comparison to the control. The decreased PCV values in exposed fish indicated that the fish are prone to becoming anaemic (Adeyemi et al. 2014). The significant decrease in the RBC counts and PCV values recorded in fish exposed to BPA and analogues in this study was similar to the findings of similar studies that also reported significant reduction in the RBC counts and PCV values in fish under stress conditions (Aiswarya and James 2016).

The total and differential leucocytes counts have been widely employed as biomarkers of immune dysfunction in fish (Roberts, 2001). Exposure to bisphenols caused a significant increase in the total WBC counts compared to the control. Also, the differential leukocytes counts showed a significant decrease in number of lymphocytes but an increase in the number of monocytes and neutrophils in exposed group compared to control. The increase in the WBC counts may be due to WBCs being an important components of the immune system through phagocytosis. The cellular production of WBCs increases in the presence of foreign bodies. The lymphopenia condition observed in this study might be due to damages induced by bisphenols to the hematopoietic system, thus disrupting the entire immune system. Elevated level of neutrophil and monocytes is an indication of tissue inflammation caused by exposure to bisphenols. Similar findings were reported in C. gariepinus exposed to 4-nonylphenol (Mekkawy et al. 2011; Abou Khalil et al. 2017).

Furthermore innate humoral immune parameters such as levels of nitric oxide and respiratory burst has been extensively used to monitor the immune response of fish to contaminant exposure (Wink et al. 2011). The exposure of C. gariepinus to bisphenols resulted in significant elevated level of nitric oxide and respiratory burst compared to the control fish. The nitric oxide is an important signalling molecule in inflammatory response in fish (Rombout et al. 2005; Kumar et al. 2019). Generally, in response to stress, the cellular levels of nitric oxide increases as was the case in the present study. Similarly, the exposure of zebra fish (Danio rerio) to the pesticide, pyriproxyfen caused a significant increase in nitric oxide level (Maharajan et al. 2018). It is assumed that respiratory burst occurs in fish during vigorous consumption of oxygen leading to the discharge of superoxide anion and its derivative by phagocytes (Chakrabarti et al. 2014). The high respiratory burst recorded in this study might be an indication heightened phagocytic action to counter the toxic effect brought about by exposure to the bisphenols. Indeed, increased respiratory burst has been reported in similar studies with fish species following exposure to various xenobiotics (Sakai et al. 2001; Chakrabarti et al. 2014).

Comparatively, the cytotoxic effects, redox imbalance, and immune dysfunction caused by BPA, BPAP, and BPP were different in magnitude. The data from cytotoxicity assays, oxidative stress, and haemato-immune parameters that were determined in this study indicated that BPA was the most toxic, followed by BPAP while BPP was the least toxic of the three.

\section{Declarations}

Ethics approval: The experimental procedures were in conformity with national and international standards on the use of laboratory animals. Also, the study was approved by institutional committee on the care and use of animal for experiments.

Page $7 / 14$ 
Consent to participate: Not applicable.

Consent for publication: Not applicable.

Availability of data and materials: All data sets, on which the conclusions of the manuscript rely on, are present in the results section in the manuscript.

Competing interests: The authors declare that they have no competing interest.

Funding: There was no specific grant from funding agencies in the public, commercial or not-for-profit sectors.

Author's contribution: JAA, FB, and COA were involved in the design of the experiment. ODS, JAA, OSB were involved in data acquisition and analyses. ODS, JAA, and OSB were involved in writing the draft of the manuscript. JAA, FB, and COA were involved in writing the final draft of the manuscript.

Acknowledgements: The authors are grateful to Mr Ojuola Micheal Olayemi for his assistance with collection of blood samples from the fish.

\section{References}

1. Abdel-Tawwab M, Hamed HS (2018) Effect of bisphenol A toxicity on growth performance, biochemical variables, and oxidative stress biomarkers of Nile tilapia, Oreochromis niloticus (L.). J Appl Ichthyol 00:1-9

2. Abou KN, Abd-Elkareem M, Sayed A (2017) Nigella sativa seed protects against 4 nonylphenol-induced hematotoxicity in Clarias gariepinus (Burchell, 1822) oxidant/antioxidant rebalance. Aqua Nut 23:1467-1474

3. Adeyemi JA (2014) Oxidative stress and antioxidant enzymes activities in the African catfish, Clarias gariepinus experimentally challenged with Escherichia coli and Vibrio fischeri. Fish Physiol Biochem 40:347-354

4. Adeyemi JA, Arowolo OK, Olawuyi ST, Alegbeleye D, Ogunleye A, Bamidele OS, Adedire CO (2018) Effect of co-administration of green tea (Camelia sinensis) on clove- (Syzygium aromaticum) induced hepatotoxicity and oxidative stress in Wistar rats. Indian J Physiol Pharmacol 62:195-201

5. Adeyemi JA, Gallimberti M, Olise CC, Rocha BA, Adedire CO, Barbosa Jr F (2020) Evaluation of bisphenol A levels in Nigerian thermal receipts and estimation of daily dermal exposure. Environ Sci Pollut Res 27:37645-37649

6. Aebi H (1984) Catalase in vitro. Methods Enzymol 105:121-126

7. Aiswarya R, James K (2016) Effect of bisphenol A on certain hematological parameters of Heteropneustes fossilis, Bloch. Int J Emerg Trends Sci Technol 3:4493-4497

8. Albuquerque DMN, Lopes JB, Ferraz MS, Ribeiro MN, Silva SRG, Costa EMS, Lima DCP, Ferreira JDM, Gomes PEB and Lopes JCO (2017) Vitamin E and organic selenium for broilers from 22 to 42 days old: performance and carcass traits. An Acad Bras Cienc 89:1259-1268

9. Anderson DP, Siwicki AK (1995) Basic haematology and serology for fish health programs. In Shariff M, Arthur JR, Subasinghe RP (eds.) Diseases in Asian aquaculture ii. Fish health section. Manila: Asian Fish Soc P 85-202

10. Arnold SM, Clark KE, Staples CA, Klecka GM, Dimond SS, Caspers N, Hentges SG (2013) Relevance of drinking water as a source of human exposure to Bisphenol A. J Expo Sci Environ Epidemiol 23:137-144

11. Azevedo LF, Carneiro MFH, Dechandt CRP, Cassoli JS, Alberici LC, Barbosa Jr F (2020) Global liver proteomic analysis of Wistar rats chronically exposed to low-levels of bisphenol A and S. Environ Res 182:109080

12. Azevedo LF, Dechandt CRP, Rocha CCS, Carneiro MFH, Alberici LC, Barbosa Jr F (2019) Long- term exposure to bisphenol A or S promotesglucose intolerance and changes in hepatic mitochondrial metabolism in male Wistar rats. Food Chem Toxicol 132:110694

13. Beauchamp C, Fridovich I (1971) Superoxide dismutase: improved assays and an assay applicable to acrylamide gels. Anal Biochem 44:276-287

14. Bradford M (1976) A rapid and sensitive method for the quantitation of microgram quantities of protein utilizing the principle of protein-dye binding. Anal Biochem 72:248-254

15. Chakrabarti S, Poidevin M, Lemaitre B (2014) The Drosophila MAPK p38c 354 regulates oxidative stress and lipid homeostasis in the intestine. PLoS Genet 10:355- 1004659

16. Chen D, Kannan K, Tan H, Zheng Z, Feng YL, Wu Y (2016) Bisphenol analogues other than BPA: environmental occurrence, human exposure, and toxicity-a review. Environ Sci Technol 50:5438-5453

17. Crain DA, Eriksen M, Iguchi T, Jobling S, Laufer H, LeBlanc GA, Guillette LJ Jr (2007) An ecological assessment of bisphenol-A: evidence from comparative biology. Reprod Toxicol 24:225-239

18. Ellman GL (1959) Tissue sulfhydryl groups. Arch Biochem Biophys 82:70-77

19. Faheem M, Lone KP (2018) Oxidative stress and histopathologic biomarkers of exposure to Bisphenol-A in the freshwater fish Ctenopharyngodon idella. Braz J Pharm Sci 53:1-9

20. Flint S, Markle T, Thompson S, Wallace E (2012) Bisphenol A exposure, effects, and policy: a wildlife perspective. J Environ Manag 104:19-34

21. Gercel-Taylor C (1982) Diphenylamine assay of DNA fragmentation for chemosensitivity testing. doi: 10.1385/1-59259-889-7:079

22. Global Industry Analysts Inc (2015) Bisphenol A market trends. Retrieved from https://www.strategyr.com/MarketResearch/Bisphenol_A_Market_ Trends.asp. 
23. Guevara-Guzman R, Emson PC, Kendrick KM (1994) Modulation of in vivo striatal transmitter release by nitric oxide and cyclic GMP. J Neurochem 62: $807-810$

24. Han L, Cai S, Gao M, Hasegawa J, Wang P, Zhang J, Zhang D (2019) Selective catalytic reduction of NOx with $\mathrm{NH}_{3}$ by using novel catalysts. State of the art and future prospects. Chem Rev 119:10916-10976

25. Howell BF, Mccune S, Schaffer R (1979) Lactate-to-pyruvate or pyruvate-to-lactate assay for lactate dehydrogenase: a re-examination. Clin Chem 25:269-272

26. Huang YQ, Wong CKC, Zheng JS, Bouwman H, Barra R, Wahlstrom B, Neretin L, and Wong MH (2012) Bisphenol A (BPA) in China: A review of sources, environmental levels, and potential human health impacts. Environ Int 42:91-99

27. Kaya Ö, Kaptaner B (2016) Antioxidant defense system parameters in isolated fish hepatocytes exposed to Bisphenol A Effect of vitamin C. Acta Biol Hung 67:225- 235

28. Krishnapriya K, Shobana G, Narmadha S, Ramesh M, Maruthappan V (2017) Sublethal concentration of bisphenol A induces hematological and biochemical responses in an Indian major carp Labeo rohita. Ecohydrol Hydrobiol 17:306-313

29. Kumar N, Sharma JG, Singh SP, Singh A, Krishna VH, Chakrabarti R (2019) Validation of growth enhancing, immunostimulatory and disease resistance properties of Achyranthes aspera in Labeo rohita fry in pond conditions. Heliyon 5:01246

30. Kumar V, Sankaranarayanan M, Durgapal M, Zhou S, Ashok S, Park S (2013) Simultaneous production of 3-hydroxypropionic acid and 1,3propanediol from glycerol using resting cells of the lactate dehydrogenase-deficient recombinant Klebsiella pneumonia overexpressing an aldehyde dehydrogenase. Bioresour Technol 135: 555-563

31. Kwak HI, Bae MO, Lee MH, Lee YS, Lee BJ, Kang KS, Chae CH, Sung HJ, Shin JS, Kim JH, Mar WC, Sheen YY, Cho MH (2001) Effects of nonylphenol bisphenol A and their mixture on the viviparous swordtail fish (Xiphophorus helleri). Environ Toxicol Chem 20:787-795

32. Lakshmaiah G (2016) Acute lethal and chronic sublethal toxic stress induced alterations in lactate dehydrogenase activity of phorate intoxicated freshwater fish Cyprinus carpio. Int J Fish Aquat Stud 4:685-689

33. Madhu S, Pooja C (2015) Acute Toxicity of 4-nonylphenol on haemotological profile of Fresh water Fish Channa punctatus. Res J Recent. Sci 4:2531

34. Maharajan K, Muthulakshmi S, Nataraj B, Mathan R (2018) Toxicity assessment of pyriproxyfen in vertebrate model zebrafish embryos (Danio rerio): A multi biomarker study. Aquat Toxicol 196:132-145

35. Martínez JG, García VA, Carrasco SP (2012) DNA fragmentation and membrane damage of Bocachico Prochilodus magdalenae (Ostariophysi: Prochilodontidae) sperm following cryopreservation with dimethylsulfoxide and glucose. Neotrop Ichthyol 10:577-586

36. Mekkawy Al, Mahmoud UM, Sayed AE (2011) Effects of 4-nonylphenol on blood cells of the African catfish Clarias gariepinus (Burchell, 1822). Tissue Cell 43:223-229

37. Michałowicz J (2014) Bisphenol A: Sources, toxicity and biotransformation. Environ Toxicol Pharmacol 37:738-758

38. Owolabi O, Babarinsa M (2020) Assessment of growth performance, nutrient utilization and haematological profile of Clarias gariepinus fed with nanoselenium formulated diets. IOP Conference Series: Materials Science and Engineering 805: 012014

39. Parhamifar L, Andersen H, Moghimi SM (2019) Lactate dehydrogenase assay for assessment of polycation cytotoxicity. Methods Mol Biol 1943:291-299

40. Penttilä IM, Mahlamäki E, Mononen I, Kärkkäinen P (1985) Adaptation of the May-Grünwald-Giemsa staining method for automated differential counting of blood leukocytes by a Hematrak Analyzer. Scand J Haematol 34:274-280

41. Qiu W, Chen J, Li Y, Chen Z, Jiang L, Yang M, Wu M (2016) Oxidative stress and immune disturbance after long-term exposure to Bisphenol A in juvenile common carp (Cyprinus carpio). Ecotoxicol Environ Saf 130: 93-102

42. Revathi RP, lyapparajb RA, Vasanthic P, Srinivasanc N, Munuswamyd, Palavesama A (2019) Protective responses of antioxidant enzymes against bisphenol-A induced oxidative stress in Asian Seabass Lates calcarifer. Indian J Geo-Mar Sci 49:1458-1463

43. Roberts RJ, Ellis AE (2001) The anatomy and physiology of teleost. In: Roberts RJ (Ed) Fish Pathology. WB Saunders, Philadelphia, USA

44. Rochester JR (2013) Bisphenol A and human health: a review of the literature. Reprod Toxicol 42:132-155

45. Rombout JH, Huttenhuis HBT, Picchietti S, Scapigliati S (2005) Phylogeny and ontogeny of fish leucocytes. Fish Shellfish Immunol 19:441-455

46. Rusia V, Sood SK (1992) Routine haematological tests. In: Mukerjee KL(Ed) Medical Laboratory Technology. McGraw Hill Publishing Co. Ltd, 252258

47. Sakai AK, Allendorf FW, Holt JS, Lod DM, Molofsky JKA, Weller SG (2001) The population biology of invasive species. Ann Rev Ecol System 32:305-332

48. Sharma M, Chadha P (2015) Acute toxicity of 4-nonylphenol on haemotological profile of fresh water fish Channa punctatus. Res J of Rec Sci 4:2531

49. Shioda T, Wakabayashi M (2000) Effect of certain chemicals on the reproduction of Medaka (Oryzias latipes). Chemosphere 40:239-43

50. Snieszko SF (1960) Microhematocrit as a tool in fishery research and management. U.S. Fish \& wildlife service, Spec Sci Report Fisheries no. 341

51. Sohoni P, Tyler CR, Hurd K, Caunter J, Hetheridge M, Williams T, Woods C, Evans M, Toy R, Gargas M, Sumpter JP (2001) Reproductive effects of long-term exposure to Bisphenol A in the fathead minnow Pimephales promelas. Environ Sci Technol 35:2917- 2925

Page 9/14 
52. Talukdar B, Kalita HK, Basumatary S, Saikia DJ, Sarma D (2017) Cytotoxic and genotoxic effects of acid mine drainage on fish Channa punctata (Bloch). Ecotoxicol Environ Saf 144:72-78

53. Varshney R, Kale RK (1990) Effects of calmodulin antagonist. Int J Radiat Biol 58:733-743

54. Wink DA, Hines HB, Cheng RYS, Switzer CH, Flores-Santana W, Vitek MP, Colton CA (2011) Nitric oxide and redox mechanisms in the immune response. J Leukoc Biol 89:873-891

55. Wu M, Xu H, Yang M, Xu G (2011) Effects of chronic bisphenol A exposure on hepatic antioxidant parameters in medaka (Oryzias latipes). Toxicol Environ Chem 93:270-278

\section{Tables}

Table 1: Differential leucocyte counts in C. gariepinus exposed to different concentrations of BPA, BPAP, and BPP.

\begin{tabular}{|c|c|c|c|c|c|c|c|c|}
\hline Parameters & $\begin{array}{l}\text { Exposure } \\
\text { duration }\end{array}$ & Control & 70BPA & 140BPA & 70BPAP & 140BPAP & 70BPP & 140BPP \\
\hline \multirow{3}{*}{$\begin{array}{l}\text { Lymphocytes } \\
\text { (\%) }\end{array}$} & 7 days & $87.00 \pm 0.58^{\mathrm{dA}}$ & $81.67 \pm 0.33^{b c}$ & $77.00 \pm 0.58^{\mathrm{aC}}$ & $82.67 \pm 0.33^{b c B}$ & $80.33 \pm 0.88^{b c}$ & $85.00 \pm 0.58^{\mathrm{cdB}}$ & $81.67 \pm 0.33^{\mathrm{bB}}$ \\
\hline & 14 days & $87.67 \pm 0.33^{\mathrm{dA}}$ & $77.00 \pm 0.33^{\mathrm{bB}}$ & $73.00 \pm 0.58^{\mathrm{aB}}$ & $80.00 \pm 0.58^{c B}$ & $76.00 \pm 0.58^{\mathrm{bB}}$ & $81.67 \pm 0.33^{\mathrm{cA}}$ & $79.33 \pm 0.334^{c B}$ \\
\hline & 21 days & $88.43 \pm 0.23^{\mathrm{eA}}$ & $73.33 \pm 0.88^{\mathrm{bA}}$ & $67.33 \pm 0.57^{\mathrm{aA}}$ & $77.33 \pm 0.33^{\mathrm{cA}}$ & $73.67 \pm 0.58^{\mathrm{cdA}}$ & $79.67 \pm 0.33^{\mathrm{dA}}$ & $75.00 \pm 0.67^{\mathrm{bcA}}$ \\
\hline \multirow[t]{3}{*}{$\begin{array}{l}\text { Monocytes } \\
(\%)\end{array}$} & 7 days & $8.00 \pm 0.57^{\mathrm{aA}}$ & $13.00 \pm 0.33^{\mathrm{cA}}$ & $16.00 \pm 0.59^{\mathrm{dA}}$ & $12.67 \pm 0.33^{\mathrm{bcA}}$ & $13.67 \pm 0.58^{\mathrm{cA}}$ & $10.67 \pm 0.58^{\mathrm{bA}}$ & $12.67 \pm 0.33^{\mathrm{bcA}}$ \\
\hline & 14 days & $7.33 \pm 0.88^{\mathrm{aA}}$ & $16.67 \pm 0.58^{\mathrm{cdB}}$ & $18.67 \pm 0.32^{\mathrm{dB}}$ & $14.00 \pm 0.58^{\mathrm{bcB}}$ & $16.67 \pm 0.33^{\mathrm{cdB}}$ & $12.33 \pm 0.33^{\mathrm{bB}}$ & $14.00 \pm 0.33^{\mathrm{bcB}}$ \\
\hline & 21 days & $7.00 \pm 0.58^{\mathrm{aA}}$ & $18.67 \pm 0.33^{\mathrm{dC}}$ & $21.33 \pm 0.33^{\mathrm{eC}}$ & $16.33 \pm 0.33^{\mathrm{cC}}$ & $18.33 \pm 0.00^{\mathrm{dc}}$ & $14.33 \pm 0.33^{b c}$ & $17.67 \pm 0.33^{\mathrm{cdC}}$ \\
\hline \multirow{3}{*}{$\begin{array}{l}\text { Neutrophil } \\
(\%)\end{array}$} & 7 days & $4.33 \pm 0.333^{\mathrm{aA}}$ & $5.33 \pm 0.33^{\mathrm{abA}}$ & $7.33 \pm 0.58^{\mathrm{bA}}$ & $5.00 \pm 0.58^{\mathrm{abA}}$ & $6.00 \pm 0.58^{\mathrm{abA}}$ & $4.33 \pm 0.33^{\mathrm{aA}}$ & $5.33 \pm 0.33^{\mathrm{abA}}$ \\
\hline & 14 days & $4.67 \pm 0.67^{\mathrm{aA}}$ & $6.33 \pm 0.33^{\mathrm{abA}}$ & $8.67 \pm 0.33^{\mathrm{bA}}$ & $6.33 \pm 0.58^{\mathrm{abB}}$ & $7.00 \pm 0.33^{\mathrm{abA}}$ & $6.00 \pm 0.33^{a b B}$ & $6.67 \pm 0.58^{\mathrm{abB}}$ \\
\hline & 21 days & $4.67 \pm 0.33^{\mathrm{aA}}$ & $8.33 \pm 0.33^{\mathrm{bB}}$ & $11.33 \pm 0.58^{\mathrm{cB}}$ & $8.33 \pm 0.33^{\mathrm{abB}}$ & $8.00 \pm 0.58^{\mathrm{abB}}$ & $5.67 \pm 0.33^{\mathrm{abB}}$ & $7.33 \pm 0.33^{\mathrm{abB}}$ \\
\hline
\end{tabular}

Means followed by same lower case in rows are not significantly different, while mean followed by the same upper case in column are not significantly different $(p>0.05)$ from one another using Tukey HSD test.

\section{Figures}



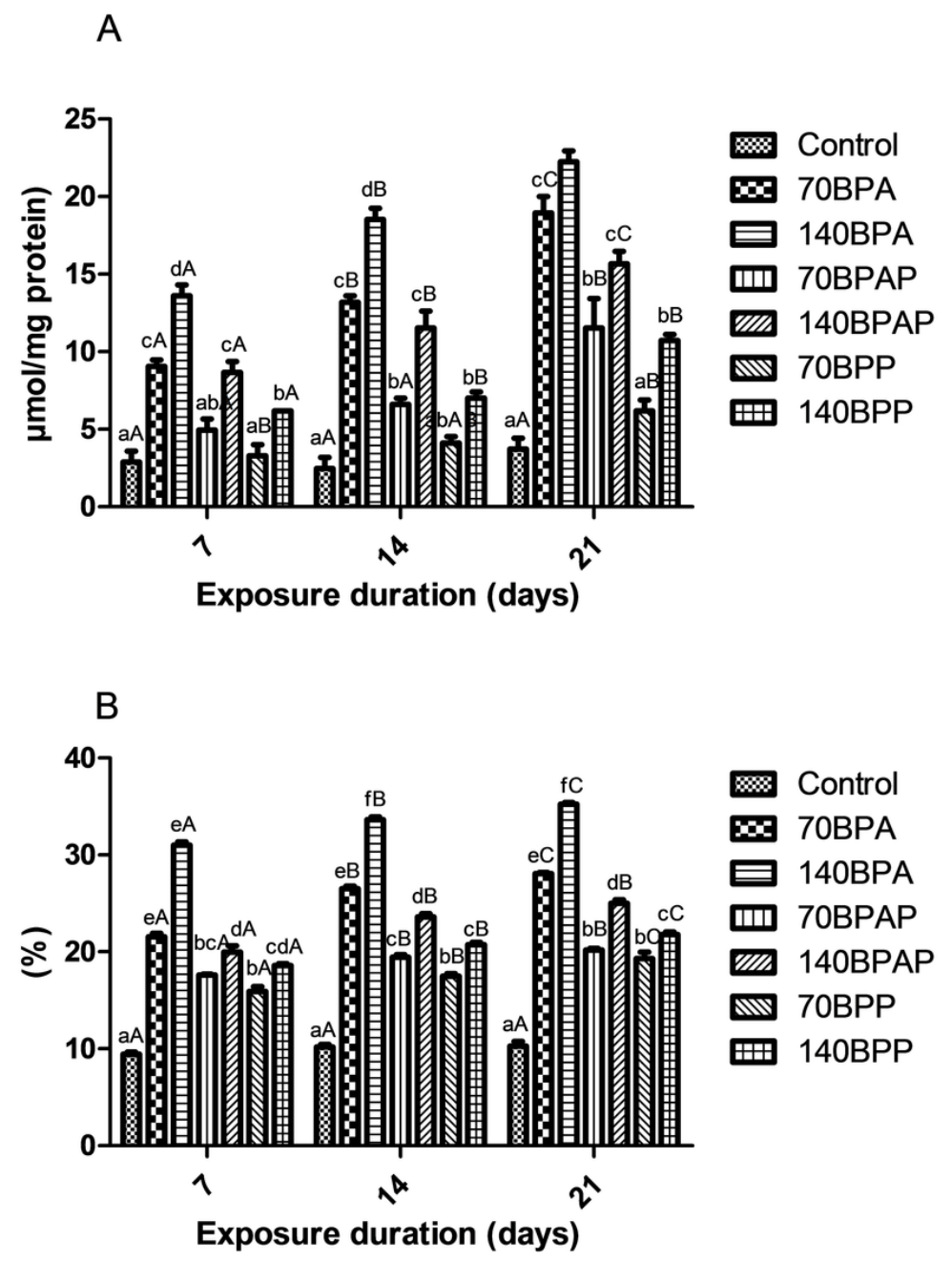

Figure 1

The activity of lactate dehydrogenase (A), and levels of DNA fragmentation (B) in C. gariepinus exposed to different concentrations of Bisphenol A, Bisphenol AP and Bisphenol P. Each bar is the mean \pm standard error $(n=5)$. Bars with different lower case letter are significant different within the same exposure duration while bars with upper case letters are significantly different for a particular treatment at different exposure durations. 

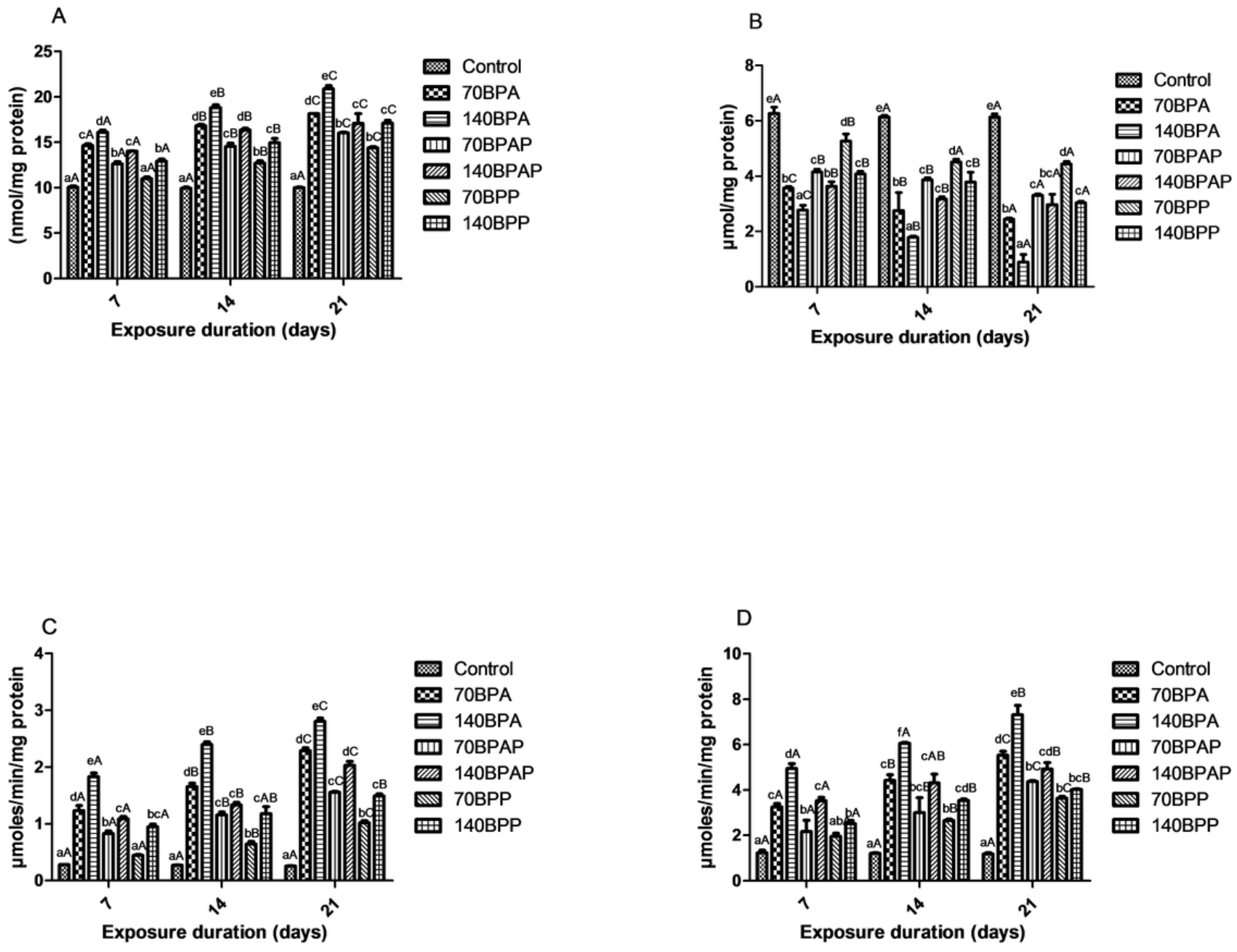

Figure 2

The levels of lipid peroxidation (A), reduced glutathione (B), activity of catalase (C) and activity of superoxide dismutase (D) in C. gariepinus exposed to different concentrations of Bisphenol A, Bisphenol AP and Bisphenol P. Each bar is the mean \pm standard error $(n=5)$. Bars with different lower case letter are significant different within the same exposure duration while bars with upper case letters are significantly different for a particular treatment at different exposure durations. 
A
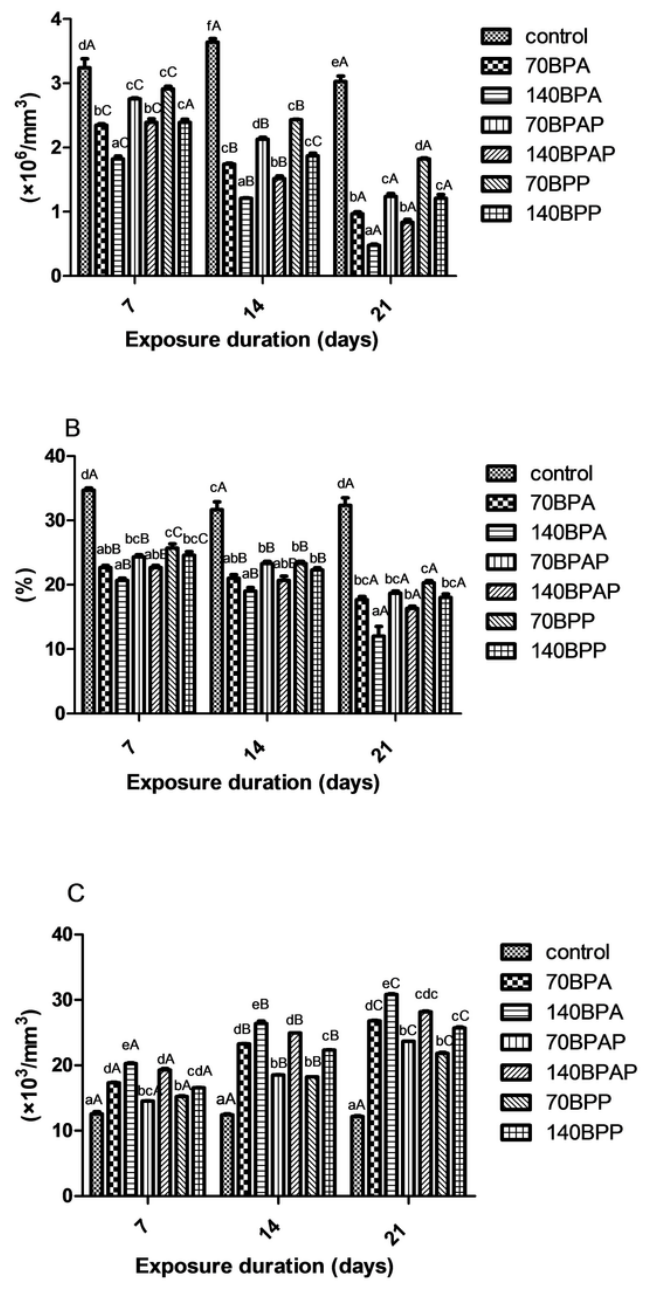

Figure 3

The red blood cell count (A), percentage packed cell volume (B) and white blood cells count (C) in C. gariepinus exposed to different concentrations of Bisphenol A, Bisphenol AP and Bisphenol P. Each bar is the mean \pm standard error $(n=5)$. Bars with different lower case letter are significant different within the same exposure duration while bars with upper case letters are significantly different for a particular treatment at different exposure durations. 

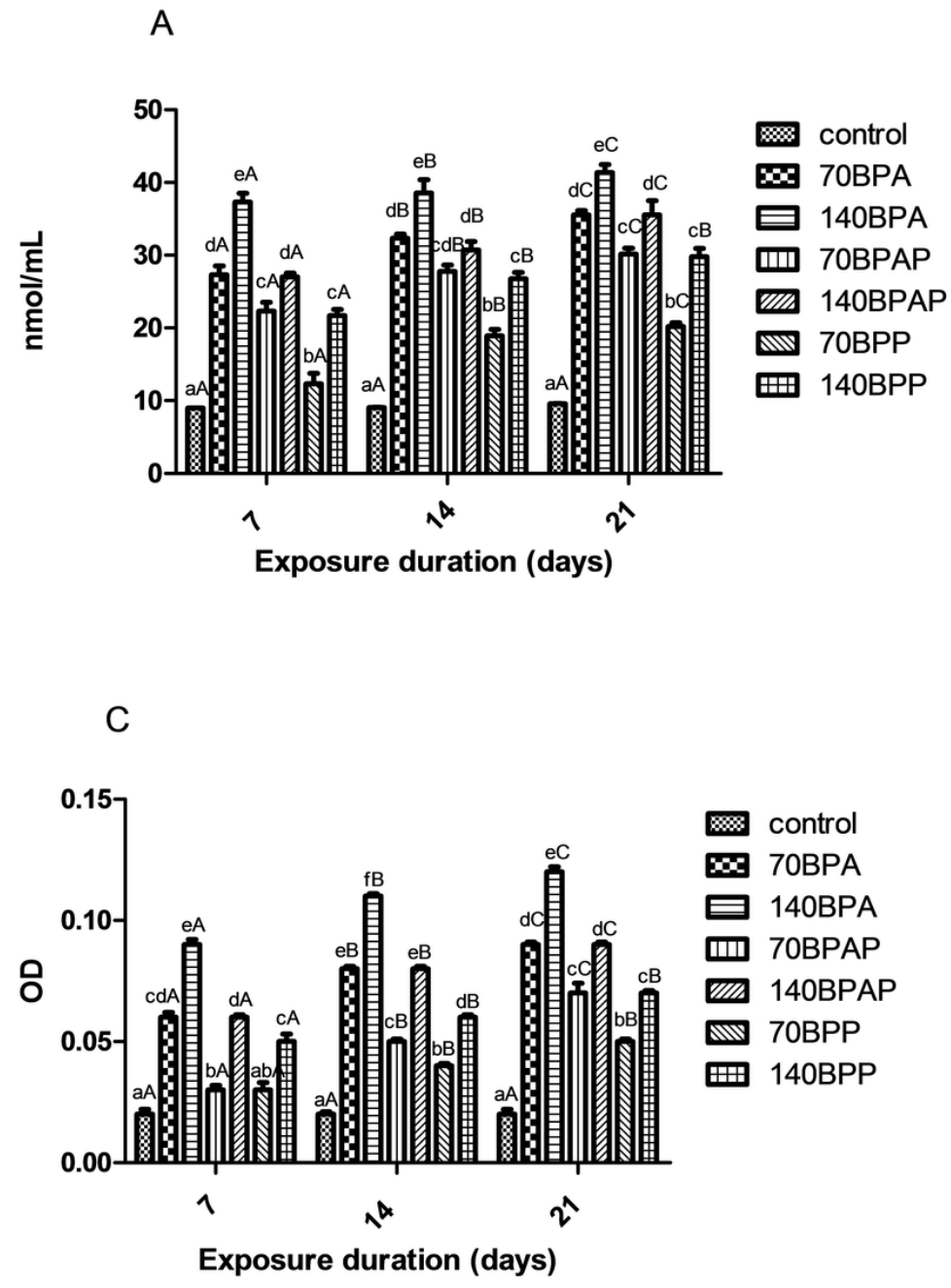

Figure 4

The levels of nitric oxide (A) and respiratory burst (B) in C. gariepinus exposed to different concentrations of Bisphenol A, Bisphenol AP and Bisphenol P. Each bar is the mean \pm standard error $(n=5)$. Bars with different lower case letter are significant different within the same exposure duration while bars with upper case letters are significantly different for a particular treatment at different exposure durations. 